Table Urinary lactulose and L-rhamnose excretion expressed as a percentage of the oral dose ingested and the lactulose:L-rhamnose excretion ratios

\begin{tabular}{llll}
\hline $\begin{array}{l}\text { Case } \\
\text { No }\end{array}$ & $\%$ Recovery & & $\begin{array}{l}\text { Lactulose: } \\
\text { L-rhamnose excretion } \\
\text { ratio }\end{array}$ \\
\cline { 2 - 4 } & Lactulose & L-rhamnose & $0 \cdot 176$ \\
\hline 1 & $2 \cdot 11$ & 11.98 & $0 \cdot 098$ \\
2 & 0.36 & 3.66 & $0 \cdot 23$ \\
3 & 0.57 & $2 \cdot 48$ & $0 \cdot 10$ \\
4 & 0.45 & 4.31 & $0 \cdot 167$ \\
5 & 0.57 & 3.42 & 0.079 \\
6 & 0.26 & 3.28 & \\
\hline
\end{tabular}

$0 \cdot 079-0 \cdot 23$ (median value $0 \cdot 13$ ) (Table). All of these ratios exceed 'normal' values.

There was no significant correlation between the level of the lactulose:L-rhamnose excretion ratio and body mass index $(r=-0.0594)$, forced vital capacity, $(r=-0 \cdot 717)$, or forced expiratory volume in one second: forced vital capacity ratio $(r=-0 \cdot 217)$ in these patients.

\section{Discussion}

This study supports the hypothesis that there is an intestinal component to the malabsorption of cystic fibrosis. The mechanism of this intestinal dysfunction is yet to be elucidated. It seems unlikely that alterations in carrier mediated transport mechanisms are important, as mediated processes contri- bute little to the absorption of lactulose and Lrhamnose. ${ }^{4}$ It has been proposed that the presence of abnormal mucus overlying the intestinal mucosa may alter transport kinetics. ${ }^{3}$

The clinical implications of this intestinal mucosal dysfunction in cystic fibrosis remain to be explored. In this small group of subjects the lactulose:Lrhamnose excretion ratio did not correlate with any of the simple clinical variables selected.

We thank the children and their physicians Dr Watson and Dr McMahon. We thank Ms E Drummond for typing the manuscript.

\section{References}

${ }^{1}$ Morin CL, Roy CC, Lasalle R, Bonin A. Small bowel mucosal dysfunction in patients with cystic fibrosis. $J$ Pediatr 1976;88:213-6.

2 Schaad U, Kraemer R, Gaze H, Hadorn B. One hour blood xylose in cystic fibrosis. Arch Dis Child 1978;53:756-7.

${ }^{3}$ Frase LL, Strickland AD, Kachel GW, Krejs GJ. Enhanced glucose absorption in the jejunum of patients with cystic fibrosis. Gastroenterology 1985;88:478-84.

${ }^{4}$ Menzies IS, Laker MF, Pounder R, et al. Abnormal intestinal permeability to sugars in villous atrophy. Lancet 1979;ii:1107-9.

5 Ford RPK, Menzies IS, Phillips AD, Walker-Smith JA, Turner MW. Intestinal sugar permeability: relationship to diarrhoeal disease and small bowel morphology. Journal of Pediatric Gastroenterology and Nutrition 1985;4:568-74.

${ }^{6}$ Cotes JE. Lung function. 4th ed. London: Blackwell Scientific Publications, 1979.

Correspondence to Dr S M Basheer, Department of Paediatrics, Limerick Regional Hospital, Dooradoyle, Limerick, Ireland.

Received 25 June 1986

\title{
Gastrografin in acute meconium ileus equivalent
}

\author{
S M O'HALLORAN, J GILBERT, O M MCKENDRICK, H M L CARTY, AND D P HEAF \\ Departments of Child Health and Radiology, Alder Hey Children's Hospital, Liverpool
}

SUMmaRY Twenty five $(37 \%)$ patients with cystic fibrosis attending our clinic have experienced acute meconium ileus equivalent. In one year 37 of 40 episodes were treated with single dose oral Gastrografin with an $81 \%$ success rate, $75 \%$ being treated as outpatients. Patients found this treatment preferable to other recommended treatment.

Meconium ileus equivalent is an important complication of cystic fibrosis that reports have suggested occurs in $10-20 \%$ of patients. ${ }^{12}$
Treatment is primarily preventative, using $\mathrm{N}$ acetylcysteine, laxatives, and, in some cases, adjustment of pancreatic enzyme supplements. Surgery during acute attacks carries a high mortality and morbidity from bleeding, poor wound healing, and postoperative chest infections ${ }^{3}$ and should be avoided through effective medical treatment. $\mathrm{N}$ Acetylcysteine given both by nasogastric tube and by enema three times daily ${ }^{3}$ and Gastrografin enemas ${ }^{4}$ have been used successfully but are unpleasant and require admission to hospital. There is little published information about oral Gastrografin in relief of acute meconium ileus equivalent. 


\section{Patients and methods}

Sixty seven patients aged 9 months to 23 years (mean age 9.8 years) who were attending the cystic fibrosis clinic at our hospital were entered into the study. Those who had experienced meconium ileus equivalent were noted, and those who had had episodes during a recent 12 month period were compared in detail with those who have never had meconium ileus equivalent.

Meconium ileus equivalent was defined as: colicky abdominal pain with a mass in the right iliac fossa plus either constipation or typical $x$ ray changes, or both. ${ }^{4}$

The two groups were compared for sex, meconium ileus at birth, type of pancreatic enzyme supplement, and chronic Pseudomonas chest infection, using Fisher's exact probability test, and for age, Schwachman score, number of admissions to hospital, quantity of pancreatic enzyme supplement, and stool frequency, using the Mann-Whitney $U$ test.

\section{Results}

Twenty five patients (37\%) had had meconium ileus equivalent at some time. Fourteen children suffered a total of 40 episodes during a one year period.

Characteristics of the children with meconium ileus equivalent during the study and of those who had never had meconium ileus equivalent $(n=42)$ are shown in the Table.

Twelve patients had experienced recurrent meconium ileus equivalent and were treated prophylacti- cally during the study year, 10 with regular oral $\mathrm{N}$ acetylcysteine and eight with laxatives.

A single dose of oral Gastrografin was given at the onset of symptoms on 37 occasions in 11 children. Four children aged 3-8.5 years received $50 \mathrm{ml}$ and seven aged 6.6-19.3 years received $100 \mathrm{ml}$. All were asked to drink at least four times that volume of water or fruit squash.

Vomiting of the Gastrografin soon after it was taken occurred three times. The children, however, did not continue to vomit, and Gastrografin was subsequently tolerated well when the dose was divided over several hours. There were no other complications.

Thirty episodes $(81 \%)$ were treated with a single dose. A second dose 24 hours later was needed on six occasions. Treatment failed only once, in an 11 year old girl who subsequently responded to a Gastrografin enema.

Twenty eight episodes $(75 \%)$ were treated on an outpatient basis. Nine episodes were treated in hospital, but in only six (16\%) was admission primarily for treatment of meconium ileus equivalent.

\section{Discussion}

Meconium ileus equivalent is a troublesome and potentially fatal complication of cystic fibrosis, the aetiology of which remains obscure. ${ }^{1}$ We have found it to be more common than has previously been reported and to occur most often in older children who have more severe manifestations of cystic fibrosis and who are admitted to hospital often. Our

Table Comparison of characteristics of children with meconium ileus equivalent and those who had never had meconium ileus equivalent during a 12 month period

\begin{tabular}{|c|c|c|c|}
\hline & \multicolumn{2}{|l|}{ Group } & \multirow[t]{2}{*}{ p Value } \\
\hline & $\begin{array}{l}\text { With meconium } \\
\text { ileus equivalent }\end{array}$ & $\begin{array}{l}\text { Without meconium } \\
\text { ileus equivalent }\end{array}$ & \\
\hline No & 14 & 42 & NS \\
\hline $\operatorname{Sex}(F: M)$ & $11: 3$ & $20: 22$ & NS \\
\hline \multirow[t]{2}{*}{ Age (yrs) (mean (range)) } & $11 \cdot 7$ & $6 \cdot 6$ & \\
\hline & $(3 \cdot 1-19 \cdot 3)$ & $(0 \cdot 7-23)$ & $<0 \cdot 01$ \\
\hline Admissions/year (mean (range)) & $1 \cdot 86(0-5)$ & $0 \cdot 78(0-5)$ & $<0 \cdot 05$ \\
\hline \multicolumn{3}{|l|}{$\begin{array}{l}\text { Admissions/year, excluding those treated for } \\
\text { meconium ileus equivalent (mean (range)) }\end{array}$} & NS \\
\hline Meconium ileus at birth (No (\%)) & $4(28)$ & $4(9)$ & NS \\
\hline Mean Schwachman score & 74 & 85 & $<0 \cdot 05$ \\
\hline Chronic Pseudomonas chest infections (\%) & $6(42)$ & $6(14)$ & NS \\
\hline Mean No of stools/day & 2 & 1.98 & NS \\
\hline \multicolumn{4}{|l|}{ Type of enzyme (No $(\%))$ : } \\
\hline Pancrease & $10(71)$ & $24(57)$ & NS \\
\hline Other & $4(29)$ & $18(43)$ & NS \\
\hline Enzyme/meal* (Pancrease equivalent) & $2 \cdot 6$ & $2 \cdot 5$ & NS \\
\hline
\end{tabular}

NS $=$ Not significant.

${ }^{*} 1$ Pancrease $=2$ Cotazyme/Nutrizym or 3 Pancrex $v$ Forte. 
patients who had had meconium ileus equivalent did not have less well controlled steatorrhoea than those who had not had meconium ileus equivalent, and neither prophylactic treatment nor newer pancreatic enzyme supplements has reduced the incidence of meconium ileus equivalent.

The failure of prophylaxis necessitates adequate treatment to relieve attacks. Surgery is hazardous and should be avoided wherever possible. ${ }^{3}$ Currently described regimens of medical management ${ }^{34}$ are effective but unpleasant and require admission to hospital.

Gastrografin is a radiological contrast medium, containing sodium diatrizoate $100 \mathrm{mg} / \mathrm{ml}$, meglumine diatrizoate $660 \mathrm{mg} / \mathrm{ml}$, and iodine $370 \mathrm{mg} / \mathrm{ml}$, plus flavouring and wetting agents. It is hypertonic with an osmolality of $2150 \mathrm{MOsm} / \mathrm{kg} \mathrm{H}_{2} \mathrm{O}$ at $37^{\circ} \mathrm{C}$. Absorption from the intestine is minimal.

When Gastrografin is given by enema to relieve obstruction in the newborn, or in older patients with cystic fibrosis with meconium ileus equivalent, the manufacturers recommend that it be diluted fourfold with water. In our hospital children who require Gastrografin enemas to relieve meconium ileus equivalent have been given $100-200 \mathrm{ml}$ Gastrografin in three times that volume of water, under fluoroscopic control.

We have found smaller oral doses, $50 \mathrm{ml}$ in children under 8 years and $100 \mathrm{ml}$ in those 8 years and older, to be effective. All children drink at least four times that volume of water or fruit squash with the Gastrografin. None of our patients has developed dehydration after these doses of Gastrografin, and electrolytes measured in inpatients were normal.

Oral Gastrografin is contraindicated where there is pre-existing dehydration, prolonged obstruction, or evidence of acute abdomen or iodine sensitivity but may otherwise safely be given to children aged over 5 years as outpatients.

Oral Gastrografin is a simple, safe, and effective outpatient treatment. We consider it to be the treatment of choice in acute meconium ileus equivalent in cystic fibrosis.

\footnotetext{
References

${ }^{1}$ Hodson ME, Norman AP, Batten JC. Cystic fibrosis. London: Bailliere Tindall, 1983:153-7.

2 Lloyd Still JD. Textbook of cystic fibrosis. Boston: John Wright PSG, 1983:159-61, 360-1.

${ }^{3}$ Hodson ME, Mearns MB, Batten JC. Meconium ileus equivalent in adults with cystic fibrosis of the pancreas. $\mathrm{Br}$ Med $\mathrm{J}$ 1976;ii:790-1.

${ }^{4}$ Pilling DW, Steiner GM. The radiology of meconium ileus equivalent. $\mathrm{Br} J$ Radiol 1981;50:562-5.
}

Correspondence to Dr D P Heaf, Respiratory Unit, Alder Hey Children's Hospital, Eaton Road, Liverpool L12 2AP, England.

Received 6 June 1986

\title{
Spontaneous subhyaloid and retinal haemorrhages in an infant
}

\author{
N J MCLELLAN, R PRASAD, AND J PUNT \\ Departments of Child Health and Paediatric Neurosurgery, University Hospital, Queen's Medical Centre, \\ Nottingham
}

SUMMARY A 6 week old girl from a socially isolated family presented with seizures and was found to have a full fontanelle, retinal and subhyaloid haemorrhages, and anaemia. These findings were not the result of a shaking injury but of a ruptured intracerebral arterial aneurysm.

With vigilance for child abuse and awareness of the possibility of cerebral injury from shaking increasing, alternative explanations of the characteristic clinical features of shaking may be overlooked. We describe a child in whom the initial impression of abusive shaking was false.

\section{Case report}

The girl was born uneventfully at term weighing $3300 \mathrm{~g}$, the first child to unmarried white parents living in poor circumstances. Her mother was aged 16 and her father 21 and unemployed. On the day of the child's admission at the age of 6 weeks, her father thought she was well when he fed her at $0600 \mathrm{~h}$. Four hours later her mother noticed a one minute episode of twitching of the left arm and hand. Similar episodes occurred at each feed of the day, but she sucked well and seemed normal between them. She screamed uncontrollably during her evening bath, with a further left sided seizure. At $2300 \mathrm{~h}$ she awoke screaming and looked pale and 